\title{
KAJIAN KONSEPTUAL PERILAKU PROSOSIAL DALAM PERSPEKTIF PSIKOLOGI SOSIAL
}

\author{
Muhammad Irfan Islamy \\ UIN Maulana Malik Ibrahim Malang
}

\begin{abstract}
:
Human are homo economicus creatures who always trying to maximize their satisfaction by acting rationally, but they have a desire to see the happiness of others, its called prosocial behavior. Prosocial behavior intended to benefit another", is a social behavior that benefits other people or society as a wholesuch as helping, sharing, donating, and volunteering, human beings as homoeconomicus beings also known as homo socius.
\end{abstract}

Keywords: Prosocial, Behavior

\section{A. PENDAHULUAN}

Sebagai makhluk ekonomi, manusia selalu bertindak rasional, yaitu selalu memperhitungkan sebab akibat dalam rangka pemenuhan kebutuhannya sehingga tidak merugikan dirinya sendiri. Manusia akan berusaha memaksimalkan kepuasannya selama kemampuan finansialnya memungkinkan. Mereka memiliki pengetahuan tentang alternatif produk yang dapat memuaskan kebutuhan mereka. Namun manusia sebagai makhluk ekonomi bukanlah makhluk egois yang hanya mementingkan dirinya sendiri dan mengorbankan orang lain untuk memenuhi kebutuhannya, tetapi pada dasarnya manusia tetap bertindak sebagai makhluk sosial.

Akibat individu ditempatkan sebagai makhluk rasional yang berorientasi kepada motif ekonomi, maka seluruh atribut sosial yang berada di sekitar individu menjadi tidak bermakna. Atribut semacam etnisitas, stratifikasi sosial, agama, budaya, keyakinan, dan lain-lain, hanyalah hiasan pewarna hidup yang tidak bakal terpantul dalam kegiatan ekonomi.

Individu dianggap akan memanfaatkan pendapatan yang diterima untuk memuaskan kebutuhannya. Kepuasan tersebut diukur dari pemenuhan kebutuhan lahiriah, seperti makanan, pakaian, mobil, rumah, dan lain-lain. Pada titik ini, dianggap semua makhluk akan memiliki perilaku seperti itu, apapun agama, budaya, maupun keyakinannya. Perilaku di luar itu hanyalah anomali, eksistensinya dipandang tidak penting. Jadi, dalam urusan ekonomi individu adalah makhluk asosial. 
Adam Smith (Deliarnov, 2006:26) secara ekspresif mengeliminasi motif-motif lain selain kepentingan pribadi. Asumsi bahwa manusia adalah makhluk rasional yang akan berusaha memilih alternatif terbaik dari berbagai pilihan yang tersedia. Bagi Smith, manusia adalah binatang yang gelisah, dan sudah merupakan khuluk manusia untuk menjadi homo economicus, yaitu sebagai makhluk rasional yang didorong oleh kepentingan pribadi untuk selalu berusaha untuk mendapatkan hasil sebesar-besarnya dari berbagai kemungkinan pilihan yang ada. Smith (Deliarnov, 2006:27) mengakui adanya kecondongan dan kepatutan manusia dalam hidup bermasyarakat. Smith tidak menyangkal ada motif-motif lain yang menggerakkan orang melakukan sesuatu tindakan.

Dalam Moral Sentiment (1759) Smith menyatakan, How selfish soever man may be supposed, there are evidently some principles in his nature, which interest him in the fortunes of others, and render their happiness necessary to him, though he derives nothing from it, except the pleasure of seeing it (Peter Minowitz, 1993:53)

Meskipun manusia dianggap egois, jelas terdapat sejumlah prinsip dalam khuluknya yang menjadikannya tertarik pada nasib baik orang lain, dan membuat kebahagiaan mereka menjadi hal penting baginya, meskipun dia tidak mendapatkan apa-apa dari tindakannya, inilah dasar yang meyakinkan ketika Smith menyatakan bahwa manusia adalah homo socius.

Tindakan menolong yang nampak dimotivasi oleh keinginan untuk mendapatkan keuntungan material disebut prosocial behavior. Namun sebaliknya tindakan menolong yang tidak dimotivasi oleh keinginan untuk mendapatkan keuntungan dalam psikologi disebut dengan altruistic behavior, dalam hal ini bila seseorang menolong orang lain, maka akan memberikan rasa senang pada orang yang menolong. Sebaliknya bila gagal akan memunculkan rasa tidak nyaman pada diri seseorang saat melihat penderitaan orang lain (Shelley E. Taylor, dkk., 2009:457).

\section{B. KONSEP DASAR PERILAKU PROSOSIAL}

Miftah Thoha (Miftah Thoha, 2005:33) mendefinisikan perilaku adalah "suatu fungsi dari interaksi individu dengan lingkungannya". Bahwa interaksi antara individu dengan lingkungannya dapat menentukan perilaku orang yang bersangkutan. Perilaku (KBBI, 2008:671) adalah tanggapan atau reaksi individu yang terwujud dalam gerakan (sikap), tidak saja badan atau ucapan. Sugiyono (Sugiyono, 2006:3), perilaku adalah manifestasi dari kejiwaan manusia. David G. Myers (David G. Myers, 2012:162), mengatakan bahwa perilaku adalah kepedulian dan pertolongan pada orang lain yang dilakukan secara suka rela dan tidak mengharapkan imbalan apapun. 
Menurut Bar-Tal (Desmita, 2009:236), perilaku prososial diartikan sebagai perilaku yang dilakukan secara sukarela (valuantary) yang dapat menguntungkan atau menyenangkan (benefit) orang lain tanpa antisipasi reward eksternal. Menurut Sears mendefinisikan tingkah laku prososial sebagai tingkah laku yang menguntungkan orang lain. Sehingga tingkah laku prososial menurut Sears mencakup kategori yang lebih luas; meliputi segala bentuk tindakan yang dilakukan atau direncanakan untuk menolong orang lain, tanpa mempedulikan motifmotif si penolong.

Staub (Dayakisni, Hudaniah, 2009:211), perilaku prososial dapat diartikan sebagai perilaku yang menguntungkan penerima, tetapi tidak memiliki keuntungan yang jelas bagi pelakunya. Selain itu, tujuan dari tindakan prososial ada dua arah yaitu untuk diri sendiri dan untuk orang lain. Untuk diri sendiri lebih ditekankan untuk memperoleh penghargaan seperti perasaan berharga dapat menolong orang lain karena dengan menolong orang lain kita akan merasa terbebas dari perasaan bersalah. Sedangkan tujuan untuk orang yang dikenai tindakan adalah untuk memenuhi kebutuhan atau hasrat orang yang bersangkutan.

Sedangkan William (Putra Giri, 2011:16) membatasi perilaku prososial lebih rinci sebagai perilaku yang memiliki intensi untuk mengubah keadaan fisik atau psikologis penerima bantuan dari kurang baik menjadi lebih baik secara material maupun psikologis dengan tujuan untuk menigkatkan well being orang lain. Wrightsman dan Deaux (Dayakisni, Hudaniah, 2009:212), yang menyatakan bahwa perilaku prososial merupakan perilaku yang mempunyai konsekuensi sosial positif yang ditujukan bagi kesejahteraan orang lain secara fisik maupun psikologis dan perilaku tersebut merupakan perilaku yang memberi keuntungan pada orang lain dari pada dirinya. Eisenberg (Saripah, 2006:53), perilaku prososial adalah tingkah laku seseorang yang bermaksud mengubah keadaan psikis atau fisik penerima sedemikan rupa, sehingga penolong akan merasa bahawa penerima menjadi lebih sejahtera atau puas secara material ataupun psikologis.

Perilaku prososial menurut Batson mencakup setiap tindakan yang dirancang untuk membantu orang lain, seperti dikutip dalam Sears, dkk (Sears, dkk, 2009:457) sebagai berikut:

“...Perilaku Prososial mencakup tindakan yang membantu atau dirancang untuk membantu orang lain, terlepas dari motif si penolong. Banyak tindakan prososial bukan tindakan altruistik. Perilaku prososial bisa mulai dari tindakan tanpa pamrih sampai tindakan yang dimotivasi oleh pamrih atau kepentingan pribadi...”

Menurut Staub (Putra Giri, 2011:16), ada dua indikator yang menjadi tindakan prososial, yaitu: 
1. Tindakan itu berakhir pada dirinya seperti perasaan bangga dan puas, dan tidak menuntut keuntungan pada pihak pelaku.

2. Tindakan itu menghasilkan kebaikan.

Sebuah perilaku prososial terdapat aliran bantuan yang diharapkan dapat meringankan beban si penerima bantuan tersebut, baik bantuan berupa materi atau bersifat kebendaan maupun bantuan berupa dukungan moral. Hal ini berarti bahwa perilaku prososial yang dilakukan seseorang memiliki tujuan semata-mata untuk meringankan beban pihak penerima bantuan. Hal ini sesuai dengan apa yang diungkapkan William dan Brigham bahwa perilaku prososial merupakan sebuah perilaku yang memiliki intensi untuk mengubah keadaan fisik atau psikologis penerima bantuan dari kurang baik menjadi lebih baik, dalam arti secara material dan psikologis. Sehingga dengan demikian perilaku prososial dapat dikatakan bertujuan untuk menyokong dan meningkatkan kesejahteraan atau well being orang lain, yaitu pihak penerima bantuan.

Pemaparan berbagai definisi yang dikemukakan oleh para ahli tersebut dapat disimpulkan bahwa perilaku prososial adalah suatu bentuk dukungan interpersonal yang dilakukan oleh seseorang kepada orang lain, dalam hal ini pihak yang membutuhkan, baik bantuan secara material maupun dukungan moral yang diharapkan dapat meningkatkan kesejahteraan pihak penerima bantuan, baik secara fisik maupun psikis namun tidak mendatangkan keuntungan yang jelas bagi pihak penolong, bahkan mengundang resiko tertentu.

\section{Beberapa Aspek Perilaku Prososial}

Perilaku prososial meliputi aspek-aspek (Margaret, 2010:34-35) sebagai berikut, yaitu:

1. Aspek suka menolong (helpfulness), yaitu kesediaan menolong orang lain yang sedang dalam kesulitan. Menolong meliputi membantu orang lain, memberitahu, menawarkan bantuan kepada oprang lain atau melakukan sesuatu yang menunjang berlangsungnya kegiatan orang lain. Menolong dapat diklasifikasian sebagai berikut, yaitu:

a. Casual helping, artinya memberikan bantuan kecil kepada seseorang yang baru dikenal, sebagai contoh: memberi uang seribu atau lebih kepada orang yang tidak dikenalnya.

b. Substantial personal helping, artinya memberikan keuntungan yang nyata kepada seseorang dengan mengeluarkan usaha-usaha yang cukup dapat diperhitungkan, 
sebagai contoh: memberikan bantuan berupa dana kepada lembaga sosial atau rumah ibadah.

c. Emotional helping, artinya memberikan dukungan secara emosional dan personal pada seseorang, sebagai contoh: mendengarkan cerita seorang teman yang tengah menghadapi masalah.

d. Emergency helping, artinya memberikan bantuan kepada seseorang (lebih kepada orang yang tidak dikenal) yang tengah menghadapi masalah yang serius dan mengancam keselamatan jiwa, sebagai contoh: menolong korban yang sedang kelaparan di jalan

2. Aspek kedermawanan (generosity) (Fuad Nashori, 2008:38), yaitu yaitu kesadaran untuk memberi bantuan kepada orang lain. Indikator dari aspek kedermawanan, yaitu: memiliki kesadaran untuk memberi bantuan dalam bentuk barang dan jasa, serta mampu membantu untuk kepentingan orang lain

3. Aspek empati (emphaty), yaitu kemampuan untuk memahami perasaan orang lain, dengan indikator: mampu memberikan perhatian kepada orang lain baik aspek verbal maupun non verbal.

4. Aspek memahami orang lain (understanding of others), yaitu kesediaan untuk berbagi perasaan dengan orang lain, dengan indikator: mampu memahami perasaan teman dan memiliki keinginan untuk berbagi perasaan dengan teman saat suka maupun saat duka.

5. Aspek penangangan konflik (handling conflict), yaitu kemampuan untuk menangani sebuah pertentangan dengan orang lain sehingga menemukan jalan keluar terhadap suatu masalah. Indikator dari aspek ini yaitu: mampu bersikap asertif serta mampu memberikan solusi saat konflik.

6. Aspek kejujuran (honesty), yaitu kemampuan untuk menangani sebuah pertentangan dengan orang lain sehingga menemukan jalan keluar terhadap suatu masalah. Indikator dari aspek ini yaitu: mampu bersikap asertif serta mampu memberikan solusi saat konflik.

7. Aspek inisiatif sosial (social initiative), yaitu kemampuan memulai interaksi secara positif dengan orang lain. Indikator pada aspek sosial inisiatif yaitu: memiliki kemampuan untuk memulai percakapan/aktivitas dengan orang lain dan mampu menyatakan ide/pendapatnya kepada orang lain.

\section{Beberapa Faktor Penentu Perilaku Prosial}

Perilaku prososial yang terjadi di sekitar kita tidak terlepas dari berbagai faktor. Terdapat berbagai faktor yang menentukan perilaku prososial, yaitu sebagai berikut: 
1. Kehadiran Orang lain dan Situasi.

Seseorang lebih mungkin untuk memberikan pertolongan pada situasi darurat ketika ia tengah sendirian. Ketika seseorang berada pada situasi yang ramai, dimana terdapat orang lain yang mengetahui situasi darurat tersebut, ini disebut dengan efek bystander (bystander effect) (Shelly E. Taylor, 2009:478).

Efek bystander ini cenderung mengarah pada penyebaran tanggung jawab (diffusion of responsibility) sehingga kehadiran orang lain membuat setiap individu merasa kurang bertanggung jawab secara personal untuk membantu orang lain pada situasi darurat tersebut. Artinya, semakin banyak keberadaan orang lain (bystander) pada sebuah situasi darurat, maka respon untuk berperilaku prososial pada setiap orang cenderung lebih rendah dibandingkan jika ia tengah sendirian.

Faktor situasi lain yang ikut menentukan perilaku prososial seseorang adalah kondisi lingkungan seperti cuaca dan setting lingkungan dan tekanan waktu. Menurut hasil penelitian Cunningham dalam Taylor, Peplau \& O’Sears (Shelly E. Taylor, dkk., 2009:480) disebutkan bahwa seseorang cenderung memberikan pertolongan ketika cuaca cerah dibandingkan pada saat hujan turun. Di samping itu, seseorang cenderung memberikan pertolongan ketika suasana sudah masih siang (terang) dibandingkan jika suasana sudah menjelang malam dan gelap.

Setting lingkungan juga ikut mempengaruhi seseorang dalam berperilaku prososial. Riset menunjukkan bahwa orang asing yang membutuhkan pertolongan lebih mungkin mendapatkan bantuan di kota kecil dengan kepadatan penduduk yang rendah dan intensitas kejahatan rendah dibandingkan di kota besar dengan kepadatan penduduk yang tinggi (Shelly E. Taylor, dkk., 2009:482).

Perilaku prososial yang muncul pada seseorang juga dipengaruhi oleh tekanan waktu. Ketika seseorang (pihak penolong) berada pada situasi yang mendesak, dimana dia terburuburu untuk mencapai suatu tempat atau memenuhi tuntutan tugas, maka kecil kemungkinan ia akan menolong. Hasil penelitian Batson \& Darley (Shelly E. Taylor, dkk., 2009:482) mengungkapkan bahwa orang yang berada dalam kondisi terburu-buru lebih kecil kemungkinannya untuk memberikan pertolongan dibandingkan dengan orang yang tidak terburu-buru.

\section{Faktor Penolong}

Faktor penolong lain yang ikut mendasari terjadinya perilaku prososial adalah suasana hati si penolong tersebut. Berbagai hasil penelitian para ahli mengemukakan bahwa secara umum jika seorang penolong berada pada suasana hati yang buruk serta tengah benar-benar 
memusatkan perhatian pada diri sendiri, maka orang tersebut cenderung untuk tidak memberikan pertolongan kepada orang lain (Robert A. Baron, Doon B, 2005:108).

3. Orang yang membutuhkan pertolongan.

Seorang penolong kemungkinan mempertimbangkan untuk memberikan pertolongan kepada orang yang disukai, meskipun orang yang membutuhkan pertolongan tersebut adalah orang asing yang baru dikenal. Jika si penolong memiliki ketertarikan terhadap korban, maka hal ini akan meningkatkan kemungkinan si penolong untuk memberikan pertolongan (Robert A. Baron, Doon B, 2005:109).

Seorang penolong memberikan bantuan kepada seseorang yang benar-benar membutuhkan pertolongan tersebut. Penolong cenderung mempunyai keyakinan bahwa penyebab timbulnya masalah pada orang yang ditolong tersebut berada di luar kendali orang tersebut. Sehingga, munculah perilaku prososial pada si penolong.

\section{E. Klasifikasi Perkembangan Perilaku Prososial}

Desmita (Desmita, 2009:240-244) mengklasifikasikan perkembangan perilaku prososial sesuai dengan tahapan perkembangan perilaku prososial tersebut sebagai berikut:

1. Defined Reinforcement. Pada tahap ini perilaku prososial (tindakan menolong) individu didasarkan oleh permintaan atau perintah yang disertai reward atau punishment terlebih dahulu. Perilaku prososial pada tahap ini dituntun oleh pengalaman menyedihkan atau menyenangkan tanpa rasa tanggung jawab, tugas, atau penuh pada otoritas.

2. Compliance. Pada tingkat ini perilaku prososial (tindakan menolong) individu karena tunduk pada otoritas. Individu belum memiliki inisiatif melakukan pertolongan, tapi tunduk pada permintaan atau perintah dari orang lain yang lebih berkuasa.

3. Internal Initiative \& Concrete Reward. Pada tahap ini perilaku prososial (tindakan menolong) individu karena tergantung pada penerimaan reward yang diterima. Individu mampu memutuskan kebutuhannya, orientasi egoistis dan tindakannya dimotivasi oleh keinginan mendapatkan keuntungan atau hadiah untuk memuaskan kebutuhannya. Tindakan menolong dilakukan jika seseorang merasakan kesempatan untuk menerima reward konkrit sebagai balas jasa.

4. Normative Behavior. Pada tahap ini perilaku prososial (tindakan menolong) individu dilakukan untuk memenuhi tuntutan masyarakat. Individu mengetahui berbagai macam tingkah laku yang sesuai dengan norma-norma masyarakat yang diikuti sanksi positif, serta pelanggaran norma yang diikuti sanksi negatif. Perilaku prososial (tindakan menolong) dilakukan karena diharapkan menjadi orang baik di mata orang lain. 
Orientasinya mencakup keinginan untuk menerima persetujuan dan menyenangkan orang lain. Harapan reward untuk menolong tidak konkrit namun berarti. Sehinggs perilaku prososial (tindakan menolong) individu terjadi karena alasan orang lain akan menyukai atau karena ingin mendapat sebutan sebagai orang baik.

5. Generalized Reciprocity. Pada tahap ini perilaku prososial (tindakan menolong) individu didasari oleh prinsip-prinsip universal dari pertukaran. Seseorang melakukan perilaku prososial (tindakan menolong) karena percaya kelak ketika ia membutuhkan bantuan akan mendapatkan pertolongan juga. Hal ini sebagai persetujuan timbal balik yang didasarkan kontrak abstrak. Harapan rewardnya non konkrit dan sulit dijelaskan.

6. Altruistic Behavior. Pada tahap ini perilaku prososial (tindakan menolong) individu dilakukan secara suka rela. Tindakannya semata-mata hanya bertujuan menolong dan menguntungkan orang lain tanpa mengharapkan hadiah dari luar. Tindakan menolong dilakukan karena pilihannya sendiri dan didasarkan pada prinsip prinsip moral. Sepanjang menyangkut keselamatan orang lain, individu dapat menilai kebutuhan orang lain, simpati kepada orang lain yang menderita dan membutuhkan bantuan, dan tidak mengharapkan keuntungan timbal balik untuk tindakannya.

\section{F. Kesimpulan}

Perilaku Prososial merupakan sebuah perilaku yang didasari pada kehendak untuk melakukan perbuatan menolong orang lain, yang secara teori ditentukan oleh beberapa faktor, yaitu: 1) bystander effect, 2) Faktor penolong, 3) Orang yang membutuhkan. Untuk memperkuat faktor tersebut, perilaku prososial dapat terlaksana dengan melihat perkembangan tindakannya dipengaruhi oleh, yaitu:1) Defined Reinforcment, 2) Compliance atau pemenuhan atas kehendak atau perintah orang lain, 3) Internal Initiative \& Concrete Reward, 4) Normative Behavior, 5) Generalized Reciprocity, 6) Altruistic Behavior

\section{G. Daftar Pustaka}

Baron, Robert, A., Donn Byrne, Psikologi Sosial Jilid II, Jakarta, Erlangga, Cet. 7, 2005.

Dayakisini, T., \& Hudaniah, Psikologi Sosial Edisi Revisi, Malang: UMM Press, 2009

Deliarnov, Ekonomi Politik: Mencakup Berbagai Teori dan Konsep yang Komprehensif, Jakarta: Erlangga, 2006

Desmita. Psikologi Perkembangan Peserta Didik. Bandung: PT Remaja Rosdakarya, 2009

Suroso, Fuad Nashori, Psikologi Sosial Islami, Jakarta: PT. Refika Aditama, 2008 
Hadori, Mohamat, Perilaku Prososial (Prosocial Behavior) Telaah Konseptual Tentang Altruisme (Altruism) dalam Perspektif Psikologi, Jurnal Lisan al-Hal, Volume 6 No. 1 Juni 2014.

Minowitz, Peter, Profits, Priest, and Princes, Adam Smith's Emancipation of Economics from Politics and Religion, California: Stanford University Press, 1999.

Myers, DG., Social Psychology. Michigan. Hopecollege. Michigan, 2000

Nurhidayati, Titin, Empati dan Munculnya Perilaku Altruistik Pada Masa Remaja (Studi Analisis Dunia Remaja), Jurnal Edu Islamika, Volume 4 No. 01 Maret 2012

Putra Giri. Efektivitas Bimbingan Kelompok melalui Teknik Permainan untuk Meningkatkan Perilaku Prososial Siswa. Tesis Magister Pendidikan pada SPS Bimbingan dan Konseling UPI. Bandung: tidak diterbitkan. 2011

Sears, dkk., Psikologi Sosial. (Alih Bahasa: Michael Adryanto). Jakarta: Erlangga, Ed. 5, 1985

Taylor, E., Shelley; Peplau, Anne, Letitia \& Sears, O., David. Psikologi Sosial (edisi keduabelas). Jakarta, Kencana Prenada Media Group. Ed.12, 2009

Thoha, Miftah, Perilaku Organisasi "Konsep Dasar dan Aplikasinya", Jakarta, PT. RajaGrafindo Persada, 2007 